Volume 11 No. 1 Maret 2019

P-ISSN 2086-6151 E-ISSN 2579-3438

http://ejournal.bsi.ac.id/ejurnal/index.php/wanastra

\title{
The Reasons Of The Main Character In Using Slang Words In Deadpool 2 Movie Directed By David Leitch
}

\author{
Aning Kartina ${ }^{1,}$ Maulani Pangestu ${ }^{2}$ \\ ${ }^{1}$ Universitas Bina Sarana Informatika \\ aningkar0508@bsi.ac.id \\ ${ }^{2}$ Universitas Bina Sarana Informatika \\ maulani.mpu@bsi.ac.id
}

\author{
Cara Sitasi: \\ Kartina, A., \& Pangestu, M. (2019). The Reason Of The Main Character In Using Slang Words In \\ Deadpool 2 Movie Directed By David Leitch. Wanastra, 11(1), 53-60.
}

\begin{abstract}
In a movie the main character is the most important part beside the story itself. Through the main character, we could know the meaning of the movie, the moral message etc. While in Deadpool movie the dialogue dominant by the slang words since the main character is the one who built the story then this study only focus with the main character only. The objective of this study is to find out how many slang word found and reason the main character using slang word in Deadpool 2 movie directed by David Leitch. The analysis only focused on main character dialogues. The method used in this analysis is descriptive qualitative method with the library and internet research. The analysis comes with several processes. First, watched the movie several times to find out how many slang words used by main character. Second, take note of slang words found based on the theory of Coleman and then analyzing the reason main character using slang word based on the theory of Wijaya. The results of analysis found 66 data applied. The result of analysis also found how slang words can be used by main character to express his emotions.
\end{abstract}

Keywords: Deadpool 2, Movie, Main Characters, Slang Words.

\section{INTRODUCTION}

Translation is the communication of the meaning of a source-language text by means of an equivalent target-language text. The English language draws a terminological distinction (not all languages do) between translating (a written text) and interpreting (oral or sign-language communication between users of different languages); under this distinction, translation can begin only after the appearance of writing within a language community.

A translator always risks inadvertently introducing source-language words, grammar or syntax into the target-language rendering. On the other hand, such "spill overs" have sometimes imported useful source-language calques and loanwords and have enriched target languages. Translators, including early translator of sacred texts, have helped shape the very languages into which they have translated.

Human beings cannot be separated from language; language is one of way to communicate. Language does not only about writing or speaking, but also about reading and listening. Language is also another way to express feelings. Language can be expressed through words in poet, song, story, and speech. People communicate to exchange or convey something by speaking or writing. Everyday people need to communicate each other whether directly face-to-face or indirectly, for example through smartphone, or email. Communication can be very easy through calls, text messages, and even video calls.

The important part of communication is language. English become the universal language because most of the countries use English as their first language. Many people are required to be able to speak more than one language, especially English, because if people can speak English fluently they will have no communications problem when go to other countries. In Indonesia English is very important too because now many companies in Indonesia need employees who is able to speak English. Even in elementary school there is already an English lesson.

Now learning English is not very difficult. Besides school, people can learn English by listening to English songs, watch English movies, to do communication with foreigner which are far away thorough the application social media or instant 
messages such as facebook and practice daily conversation with friends or family in English.

Along with the development of the times, language also develops. Many trend words appear and form new terms that called slang. Slang language is the variety of unofficial language consists of words and expressions which will not be found in the dictionary and its seasonal because slang are constantly changing, developing and it is an up-todate language.

Slang language is usually used every day, but it should be noted that the use of slang should be seen by whom people speak, as some of these slang words and expressions seem rude or disrespectful. Slang words do not only occur in real life, but also in song lyric or movies.

Movie is known as a motion picture, movie is an art that contains moving images that are combined into a story with the actors and actress who have a role. Movie is also a form of expression, thoughts, ideas, concepts, feelings and moods of a human being visualized into a story. Most movies are fictional stories, but there are also based on true stories.

Many movies used the slang words and Deadpool is one of them. Deadpool is American Superhero film based on the Marvel Comics character of the same name. Deadpool 2 released on May 2018 directed by David Leitch and distributed by 20th Century Fox. This movie is enjoyable because the genre movie is action with comedy and the main characters use slangwords in many situation and condition.

Based on the reason above, this study would like to analyze the slang words used by the main character in Deadpool 2 movie, types and the reasons.

\section{A. Definition of Sociolinguistics}

Sociolinguistics is the study of languages that have relationships with society. Sociolinguistics not only learns about languages but also learn about aspects of language used by society. According Herk in (Putra, 2016) Sociolinguistic is "The scientific study of the relationship(s) between language and society." It means that sociolinguistics is a study related to language and society, two fields of science that have a close relationship because language is the object of society to interact or communicate.

Meanwhile Holmes in (Meinawati \& Dewi, 2017) explained, "Sociolinguists study the relationship between language and society. They are interested in explaining why we speak differently in different social contexts, and they are concerned with identifying the social functions of language and the ways it is used to convey social meaning." It means sociolinguistics as a study that intends or aims to learn how about the relation of language use with social behavior.

In addition (Suhardianto \& Ambalegin, 2017) said "Sociolinguistics deals with the social aspects contained in society. Sociolinguistics also discusses the different variations of language used in society in describing social phenomena such as the use of slang." It means that sociolinguistics is not only about language and society, but also variation languages in society and slang is one of them.

Based on the explanation above, it is concluded that sociolinguistics is the study of the relationship of language with society, and the variations of language used to daily communicate.

\section{B. Definition of Slang Words}

Slang is an unofficial language. Slang is not included in the standard language and normally used by certain social groups. Slang language usually used in informal situation. According to Astriyani in (Aryawan, 2017) "Slang is a kind of code or secret language which is used by some people or community group in society." It means that slang language is actually a special and secret, because it has a purpose to prevent others from knowing what a group is talking about.

In addition Yanchung and Yanhong also states in (Aryawan, 2017) "Slang is part of a language that is out from the standard usage of daily life language that may consists of new vocabularies and phrases with extended meanings attached to the original terms or words that belongs to a particular group." It means that slang usually used by particular group of people, teenagers or certain social groups to communicate and varying their language in order to keep the secret of what they are talking about.

According to Keraf in (Egilistiani, Wahya, \& Darmayanti, 2015) slang word is "an informal word that arranged typically in a conversation." It means slang language sometimes often used in conversations both in oral and written in social media or instant messaging such as facebook and twitter.

Based on explanation above, it is concluded that slang is an informal language variation and usually used by teenagers and certain people or groups to communicate, expressed feeling and the meaning of the word is only known by themselves.

\section{Reasons of Using Slang Words}


Slang word can make people become more creative, because by using slang word people can create new variations of languages. According to (Wijaya, 2014b) "When someone uses slang, she/he exposes ideas, feeling, attitude as how she/he wants to perceive the people that talk to and how she/he wants those people to perceive her/him, to infer what she/he means." That means that when people use slang word, people can express ideas, feelings, moods, emotions and attitudes as they want to show to others.

According to Pardede and Kisno in (Cong \& Silitonga, 2015) "Slang can be used by those inside a group who share ideas and attitudes as a way of distinguishing themselves from others." It means slang can be used by certain group to share ideas and they can together form their own identity.

In addition Flexer in (Rachmijati, 2015) said the use of slang is "An efficient and effective way in communicating thoughts and feelings. Through slang people can make communication more quickly, easy and personal." It means that slang concept has a purpose to communication with the expression used, so that the communication process can be delivered easily and concisely.

Based on explanation above, it is concluded that the reason for certain people and group using slang word is for expressing and conveying their emotions or feeling such as love, disappointment, happy, sad and anger, so that people can communicate in easy way.

\section{Movie}

Nowadays movie became a popular thing, movie has become the most awaited entertainment today. Watching movies is a hobby most liked by people around the world, adults, teenagers and even children. Movies are progressing a lot, at first the movie is only black and white, noiseless, but with the development of the times, now the movie already has a high quality picture and sound. Movie also has many genres such as action, horror, animation, fantasy, comedy, drama, romance and more.

According to Hornby in (Putra, 2016) "Movie is a series of moving pictures recorded with sound that tells a story, shown at the cinema (movie theatre)synonym with Film." It means movie is the formation of recorded images and sounds in which there are various elements of art. Movies are produced based on composed stories, and are played by actors and actresses. In general, movie is a story that is shown in the cinema.
According to (Arfani, 2018) "Movie is a form of entertainment that enacts a story by sound and a sequence of images giving the illusion of continuous movement." It means movie is able to tell a lot in a short time only with pictures and sounds, when watching a movie the audience seems to be able to enter the story.

In addition (Safranj, 2015) states "Movies are motivating media due to encompassing various topics and they are presented with both audio and visual" It means movie can also be considered as a medium of communication and a good educator through the message contained in the film.

Based on the explanation above, it has been concluded that movie has many benefits. First, watching a movie can be for entertainment, because movies become a media that is able to provide entertainment for the public in general. Second, the film can also be a teacher because it can give a huge influence on the audience through the message contained in it.

\section{E. Main Characters}

The success of a movie can not be separated from the leading role or known as the main character, because main character can always be the main focus and the most attention to the audience. According to (Kusumawati, 2013) "Character is the most obvious form of literary representation of an individual within a larger imaginary situation." It means that movie has a wide variety of characters that complement each other, so it can provide conflict, plot, and the development of the story which are desired.

According to Koesnosobroto in (Meinawati \& Dewi, 2017) says:

"Characters can be divided into two kindly major or main character and minor character. Major character is the most important character in a story. Basically, story is about main character, but main character cannot stand alone, main character needs other characters to fill the story to be more convincing and feels alive"

From the definition above, it means that the main character plays an important role. But, the main character also needs other roles such as the existence of the supporting roles for success, so the story can be more interesting and relatable because film without another character seems flat.

Stanton also state in (Meinawati \& Dewi, 2017) "Main character is commonly used in two ways. The first is that character designates the individuals who appear in the story. The second is that 
character refers to the mixture of interests, desires, emotions, and moral principles the makes up each of these individuals." It means that in the film the main character takes the largest part of the story, in other words the main character is the most widely told figure.

Based on the explanation above, it is concluded that main characters can be said as the key to the success of a movie, because the main character is the figure that became central in the story. The main character is also helped by some supporting role so that the story can be more perfect. Therefore, it is indeed important to find the reason of the main character use the slang words and it is the reason why the writer writes this research. This research limits the object of the study on the main character only so that we can focus the reason behind the using of the slang words of the main character. We limit it into main character because the story is mostly built up by the main character.

\section{METHOD OF RESEARCH}

The objective of this study is to find out how many slang word found, types of slang words and reason the main character using slang word in Deadpool 2 movie directed by David Leitch.

The analysis only focused on main character dialogues. The method used in this analysis is using descriptive qualitative method with the library and internet research. The analysis comes with several processes.

The results of analysis found 66 data applied and found the total of 4 types of slang words are used by main character. The most types of slang words used is vulgar slang occurs 49 times, followed by teenager slang occurs 13 times, then sex slang occurs 3 times and hip hop slang occur only one time. The result of analysis also found how slang words can be used by main character to express his emotions.

Based on the explanation above, there are following steps that are done in this study. First, watched the movie several times to find out how many slang words used by main character. Second, take note of slang words found then classify the types of slang words based on the theory of Coleman and analyzing the reason main character using slang word based on the theory of Wijaya.

\section{FINDINGS AND RESULT}

The data in study are slang words spoken by the main character in Deadpool 2 movie. The movie released in 2018 in Hollywood, The United States of America and directed by David Leitch.

In this part, the writers present the research result slang words found in Deadpool 2 Movie. The writers analyze each of the main character's dialog in order to find out the slang word, the types of slang words and the reason why main character using slang word. The writers analyze the slang word used the theory as shown in before.

\section{A. Most Types of Slang Words Used by Main Character}

Deadpool 2 is American superhero film based on the Marvel Comics. Deadpool 2 tells a story about Wade Wilson a mutant named Deadpool who trying to protect a mutant named Russell who are targeted by Cable (the time traveller). Slang word can be found in Deadpool 2 movie, because the main character often used slang words.

In this section, the writer will analyze the slang words then identified types of slang word used by main character. The writer has been watched the movie several times and found many slang words occur in this movie. The writer classify the types of slang words used the theory by Coleman in (Ulhasanah, Yanti, \& Rina, 2016) there are teenager slang, vulgar slang, sex slang and hip hop slang.

Based on theory of Coleman, the writer found all types of slang words used by main character in Deadpool 2 Movie. The types and the meanings of the slang words will be presented in the following discussions.

Table 1 The types of slang words found in Deadpool 2 movie

\begin{tabular}{|c|c|c|}
\hline No. & Types of Slang & Quantity \\
\hline 1. & Teenager Slang & 13 \\
\hline 2. & Vulgar Slang & 49 \\
\hline 3. & Sex Slang & 3 \\
\hline 4. & Hip Hop Slang & 1 \\
\hline
\end{tabular}

From the table above, it can be seen that most types of slang words used by main character is vulgar slang then followed by teenager slang, sex slang and the last is hip hop slang. Then each of the types of slang words by the most used will be discussed, they are:

1. Vulgar slang is the most types of slang words used by main character, with "fuck" the most words used. In this movie the usage of vulgar 
slang is more used than the another types of slang words, because in this movie the main character often used slang words that contain rude, dirty meaning and unpleasant words in many situations and conditions.

\section{Vulgar slang}

Vulgar slang is slang words has dirty meaning, it makes this term considered as a rude. Saying these words is impolite and unplesant may bother some people, such as "fuck", "bitch" and "shit". There are 7 examples that belong to vulgar slang.

\section{Data 10}

Wade

: "Pile of shit father took off and

bailed, and.."

"It's not like I have a lot of strong role models to draw off of for

Todd.“(In Wade’s house, 00:10:11)

Vanesha: "Hey. Look at me. You are not your father."

This slang words identified as vulgar slang, because contain shit words which has rude meaning. In slang pile of shit can be used to describe a person who totally worthless and useless. In this dialogue when main character and his wife talk about family, main character said pile of shit which refer to his father, because his father left him since a kid.

\section{Data 16}

Negasonic : "Wade, Yukio. Yukio, Wade.”

Deadpool : "What in the fuck knuckle is this?"(In the X-Men's dorm, 00:22:14)

This slang words is identified as vulgar slang, because the fuck word in English has the dirty meaning which is having sexual intercourse with someone, but in slang fuck has several meaning. In this dialogue Deadpool used fuck knuckle to Negasonic, because Negasonic came and introduced her girlfriend. Fuck knuckle has meaning an idiot or annoying person.

\section{Data 20}

Deadpool : "One of the asshole who killed Vanesha got away.

Colossus : "Wade.. Whoever they are, we track them down and bring them to justice."

Deadpool : :Its me, I'm the asshole who got away." (In the X-Men's dorm, 00:24:06)
This slang word is identified as vulgar slang, because asshole has dirty meaning. In slang asshole is common word for jerk or person who doesn't treat people with respect. In this dialogues main character calling himself asshole because he can't save Vanesha, his wife. When Wade and Vanesha celebrate their anniversary, Vanesha was shot by Deadpool's enemy in their house.

2. Teenager slang is the second often used by main character, but not as much as vulgar slang. In this movie, main character used teenager slang to varieties his languages, such as "jelly" is another word for jealous.

\section{Teenager Slang}

Teenager slang is a trully popular slang word in teenage life because teenage can variation their language to replace some words which sounded too old with a new words that sounded cool. One of many reasons why teenagers like to use slang word in their daily conversation is because slang word make them more creative. There are 6 examples that belong to teenager slang;

\section{Data 5}

“Hit it dolly!" (In the Bar, 00:03:36)

Dolly is identified as types of teenager slang. In this dialogue Deadpool called dolly to woman who works at the bar, but Dolly is not her name, because dolly is a way to describing person or anything that is cute or doll-like. Dolly also can be used to call a beautiful young woman who is kind and generous, but can also be childish and playful.

\section{Data 17} Negasonic : "She's my girlfriend, you
intolerant shit"

Deadpool : : "Whoa! Pump the hate brakes, fox and friends. I'm just surprised anyone would date you." (In the X-Man's dorm, 00:22:19)

This slang words is identified as types of teenager slang, because in this dialogue the main character said pump the hate brakes to Negasonic, which the meaning is to ask someone to slow down when trying to make conclusion about someone or something.

3. Sex slang found only a few in this movie. Because in this movie main character used sex slang which is "dick" and "prick" to describe people as fool, annoying or person who like to mess around. 


\section{Sex Slang}

Today many people are using sex slang. Sex slang usually insert words like male or female genitals such as "dick" or "cock" to be produce as slang words, but this slang words does not have meaning for sex. There are 2 examples belong to sex slang;

\section{Data 45}

Domino : "Okay, I'm over the convoy. Where did the rest of the team land?"

Deadpool : "Good news and bad news." "The good news is I don't think anyone's gonna miss Shatterstar. He was a bit of prick" (In the street, 01:03:07) ]

This slang word is identified as sex slang, because prick is another words for penis or male genitals, but in slang words prick has meaning someone who is completely worthless. In this dialogue prick used by main character when he talk with Domino. Deadpool called Shatterstar prick because he is not helpful as a member of X-Force. When X-force jump from helicopter by parachuting in mission to rescue Russell, Shatterstar dead falling into another helicopter blades.

\section{Data 55}

"Because honestly, he's a bit of dick, and like a lot of dicks." (In the X-Men's dorm, 01:22:36)

Dick is identified as types of sex slang, because dick in English has meaning the male genital, but in slang words dick has meaning fool, idiot or mess around. Dick in slang words usually for man, because women can't describe as dick. In this dialogue Deadpool said dick refer to Juggernaut, because Juggernaut want to help Russell to kill the headmaster in mutant rehabilitation.

4. Hip hop slang is less used, in this movie the writer found only one word of the hip hop slang used by main character, which is "momma". Because hip hop slang is extremely rare in the movie if that has no relation with hip hop.

\section{Hip Hop Slang}

Hip hop slang usually used by certain group like rapper, hip hop slang usually can be found in song with RnB genre and rap lyric. But there are some hip hop slangs that can be used by others such as "savage", "dab". There is only one example that belongs to hip hop slang;

\section{Data 48}

“Showtime Momma" (In the street, 01:06:05)

Momma usually used by hip hop group as slang word for mother, wife or women. But momma can be used by youth people also, not only hip hop. In this dialogue Deadpool used momma to calling Domino who were driving the car to avoid Cable who wants to kill Russell.

\section{B. Reason Main Character Using Slang}

In this section, the writer analyze each of the main character's dialogues and used theory by (Wijaya, 2014a) in order to find out the reason main character using slang words. Based on theory by Wijaya, the writer has conclude that slang words can be used by certain people or group to communicate and express their feeling, moods and emotions such as love, disappointment, anger, etc.

\section{Expressing Love}

Expressing the feelings of love is something that can be done in various ways. Expressing love not only to family or lovers, but also to friends. Slang words can be used by someone to expressing their love to others.

a. (In the helicopter, 01:02:06)

"I'll never let anything happen to you, Sugarbear."

Sugarbear is a male person which personality is sweet as honey. In this dialogue, Deadpool and XForce in helicopter to rescue Russell and avoid Cable. Before jump by parachuting, Deadpool expressing love to Peter the X-Force member by calling Peter Sugarbear.

b. (In the Essex house or Mutant Rehabilitation, 01:39:59)

\section{“Hey, you're superhero now Bubba"}

Bubba used to expressing love, because bubba is a sweet nickname give to someone who is like brother, someone special or close friend. In this dialogue, when Deadpool is dying, he holds the Russell hand and calling Russell with bubba.

\section{Expressing Disappointment}

Disappointment is the expressing feeling of dissatisfaction that follows the failure of expectations. There may be times when people feeling disappointment. People might be disappointed with other people, even with ourselves. Slang can be used by someone to express their feelings of disappointment. 
a. (In the Ice Box, 00:46:03)

"What kind of spineless shit sticks tries to kill 14 years old boy?"

In this dialogue, Deadpool said shit sticks when fighting with Cable. Deadpool express his disappointment to Cable because Cable wants to kill Russell to prevent Rusell from killing Cable's family in the future. Shit sticks have meaning useless person or a person who messed around.

b. (In the X-Men's dorm, 01:23:28)

"You know what? Doing the right things is sometimes messy and fucked up, and not particullary convenient."

The main character use fucked up to express his disappointment to Colosuss, because Colosuss doesn't want to help to against Russell and Juggernaut in Mutant Rehabilitation. In this dialog the main character used fucked up is not as literal meaning, but fucked up is something that's messed up or something that didn't go right.

\section{Expressing Anger}

In everyday life, people often feel angry or annoying either to others people or something. Many slang words can be used to express anger; it means slang can be used by someone when they are angry or to express their angry feelings.

a. (In Essex house or Mutant Rehabilitation, $00: 33: 17)$

Colosuss : "Wade, what did you do?"
Deadpool : "That kid was abused. You can
tell, you can always tell."

Colosuss : "We have rules. You are not judge, jury or executioner."

Deadpool : "Fuck your rules. I fight for whats right"

Fuck is seen as the most vulgar word, fuck can be used in almost every informal situation and to express any emotion. In this dialogue main character used fuck to express his anger to Colosuss, because Colosuss do not allow Deadpool to kill people who hurt Russell in Mutant Rehabilitation.

b. (In the bar, 00:55:03)

"You shut your Goddamn trash mouth"
Goddamn usually used to expressing of anger, surprise, or frustration. Goddamn just a swear word, which is a combo of God and damn. In this dialogue Deadpool said Goddamn to his best friend named Weasel because Weasel annoying.

Above are the examples of slang words used by the main character in Deadpool 2 movie.

The writes classify the examples based on the type of the slang words.

\section{CONCLUSION}

After analyzing, the writers would like to make some conclusions about slang words of the main character in Deadpool 2 movie directed by David Leitch. Slang is informal languages used by certain people or group to communicate and the meaning of slang language is actually a special and secret, because it aims that other people not know what is being discussed. Slang words always develop and changes from time to time, that causes slang to be seasonal and not last long. Based on the discussion above, the writers get some conclusions from this research are as follows:

There are four types of slang words according to Coleman (Ulhasanah et al., 2016). In this research the writer found all the types of slang used by main character such as teenager slang, vulgar slang, sex slang and hip hop slang. In this movie, the writer managed to found many slang words used by main character, there are 66 slang words.

In this movie, the writer found all types of slang words in main character's dialogues. The writer found that the most types of slang words used by main character is vulgar slang, then teenager slang, sex slang and the last is hip hop slang. Based on the findings, vulgar slang occurs 49 times, teenager slang occurs 13 times, sex slang occurs 3 times and hip hop slang occur only one time.

The writer concludes reason the main character using slang words is to vary languages and to express emotions through slang words, because through slang words people can express and convey their emotions or feeling such as love, disappoint, anger, shock, sad and happy in easy way.

Slang words are an interesting topic to discuss, because slang words can be found everywhere. Slang words not only occur in real life such as in conversation between teenager, youth people, or certain group, but slang words can be found in movies and song lyric. After analyzing this paper, the writers understand what slang words are, the 
meaning of slang words. Types of slang and reason people using slang words, so the writer will give some suggestions that will become more useful for people who are interested with slang words. The following suggestions are below;

For the reader who wants to know about slang words, from this paper it can be learned about slang words. This paper will make people understand more about slang words even more and know how to used slang words in right situations and conditions. Using slang words also make people become more creative and increase new vocabulary, because slang words can be used in daily conversations with friend or certain group.

For the next research, the writer thinks that studying slang language would help people to variation their languages. Therefore the suggest from the writer to the next research better to learn about slang language and analyze the slang words as the topics for final assignment in the future.

\section{REFERENCE}

Arfani, S. (2018). The Schizophrenia in The Main Character of A Beautiful Mind Movie Directed by Ron Howard. Wanastra, X(1), 916.

Aryawan, L. P. K. F. (2017). An Analysis of The Use of American Slangs on Eminem's Song Lyrics, 1(2), 59-70.

Cong, D., \& Silitonga, F. (2015). The Slang in Gay Best Friend Movie, 99-110.

Egilistiani, R., Wahya, \& Darmayanti, N. (2015). International Journal of English and Education P Language Wordplay by Teenagers on Twitter in 2011 - 2013 :, 4(1).

Kartina, A., \& Pangestu, M. (2019). The Reason Of The Main Character In Using Slang Words In Deadpool 2 Movie Directed By David Leitch. Wanastra, 11(1), 53-60.

Kusumawati, F. P. (2013). The Personality of The Main Character as Reflected in Paulo Coelho's The Devil And Miss Prym : A Pscychological Study, 2(2), 158-168.

Meinawati, E., \& Dewi, S. I. (2017). Liberal Feminism of The Main Characters in Mirror Mirror Movie Based on Sociological Approach, $I X(1)$.

Putra, O. P. (2016). Slang Language in Crank II: High Voltage Movie Based on Social
Dimension, $X I(2), 31-40$.

Rachmijati, C. (2015). An Analysis of The Slang, 97-105.

Safranj, J. (2015). Advancing Listening Comprehension Through Movies. Procedia Social and Behavioral Sciences, 191, 169173.

https://doi.org/10.1016/j.sbspro.2015.04.513

Suhardianto, \& Ambalegin. (2017). Slang Language Acquisition, Construction, and Context of Used in Teenagers' Perspective of Batam City, Vol 2 No.1.

Ulhasanah, A., Yanti, Y., \& Rina, N. (2016). AN ANALYSIS OF SLANG WORDS IN THE SCARY MOVIE, Vol 2 No. https://doi.org/10.1080/00048623.2007.10721 282

Wijaya, B. S. (2014a). The use of English slang words in informal communication among 8 th semester students of English department in Binus University. Humaniora, 5(1), 197-209.

Wijaya, B. S. (2014b). The Use of English Slang Words in Informal Communication Among 8th Semester Students of English Department in Binus University. Humaniora, 5(1), 197209. 